\title{
Abur-aburan Gathutkaca: the Work of Sabet Motion of the Samberan War in the Classical Shadow Puppet Performing Arts
}

\author{
Jaka Rianto $^{1^{*}}$ Andi Wicaksono ${ }^{2}$ \\ 1. Puppetry Department, Faculty of Performing Arts, Indonesia Institute of Arts, Surakarta, Central Java, \\ Indonesia, 57126 \\ 2. Puppetry Department, Faculty of Performing Arts, Indonesia Institute of Arts, Surakarta, Central Java, \\ Indonesia, 57126 \\ *E-mail of the corresponding author: jokoriyanto63@yahoo.com
}

\begin{abstract}
This article describes the artistic research work on garap sabet of Gathutkaca character in classical shadow puppet by the artists; Jaka Rianto and Andi Wicaksono. The focus of the work is the design of abur-aburan motion and Samberan war of the creative-innovative Gathutkaca character, as well as blending them into a classical shadow puppet (wayang Purwa) performance. The method of creating works was carried out from the stage of determining ideas, studies of previous works, and literature studies. After that, the concept of the work embodied by wayang dramaturgy; sambung-rapet, and greget-sahut was formulated. The process of realizing the work was carried out by searching for the exploratory motion of Gathutkaca's sabet and making a dramatic script. The performance of the work was carried out using the rules of Surakarta-style wayang performances after the exercise stage was considered to be solid. The conclusion obtained in the process of this work is that the search for creative-innovative forms of sabet movement must be carried out with exploratory and repeated. The basic rules of cepengan, tanceban, bedholan and solah elements in working on sabet classical shadow puppet cannot be abandoned in order to achieve the aesthetics of classical shadow puppet performances.
\end{abstract}

Keywords: abur-aburan Gathutkaca, perang samberan, garap sabet, dramaturgi wayang

DOI: $10.7176 / \mathrm{JCSD} / 66-06$

Publication date:September 30th 2021

\section{Introduction}

Irika ta sang Ghațotkaca kinon mapagārkkasuta,

têkap ira Kŗșna Pārtha manêhêr muji çakti nira,

sang inujaran wawang masêmu garjjita harșa marêk,

mawacana bhagya yan hana pakon ri patik nrpati.

(When the task against Karna was accepted by Gathutkaca,

Krishna and Arjuna also praised his supernatural powers,

Ghathotkacha looked happy, so he rushed to face,

He said, "I am very pleased because of Your Highness command".

The beautiful Old Javanese verse above tells the story of Gathutkaca's character in the Bharatayuda war on the $14^{\text {th }}$ day. Gathutkaca received an order to fight against Karna, the son of god Surya who was mentioned in the text under the term arkkasuta. The verse above is an excerpt from the Kakawin Bharatayuddha by Empu Sedah and Panuluh which is commonly sung by the dalang as Sulukan Ada-ada Greget Saut in a Surakarta-style classical shadow puppet performance (Padmosoekotjo, 1978:20-23). It is not surprising that the excerpts of the two poets' poems are familiar to the puppeteers and the audience of the Surakarta-style of classical shadow puppet performance. There is an interesting side in terms of the content of the poem, namely information about the supernatural powers of the son of Bima named Gathutkaca who was famous in the $11^{\text {th }}$ century. Gathutkaca's character is still popular today. Therefore, the depiction of the Gathutkacha character and his supernatural powers is an interesting thing to be presented in a puppetry artwork.

The figure of Gathutkaca is well known to the Javanese as a knight with wire muscles and iron bones. The mention is understood as a figure who is magically powerful because it was forged by the gods when he was a 
toddler (Sudibyoprono, 1991: 220). In the forging process, he was boiled into the crater of Mount Candradimuka along with magic weapons as spices. Gathotkaca became valiant and extraordinary, then he defeated Nagapracona as mentioned in the story of Gathutkaca Jedhi. The figure of Gathutkaca became a very idolized figure, to the point that there was an area in Karanganyar Regency, Central Java which was named Pringgodani by the people. Pringgodani is the name of the country led by Gathutkaca in puppetry so that through this naming strengthens the opinion that the figure of Gathutkaca is highly idolized by the Javanese as a superhero.

The description of the Gathutkacha character who is idolized by the Javanese is not quite satisfying if it is only presented as a bedtime story; especially for fans of shadow puppet performance. The presence of the figure of Gathutkaca as a superhero is highly expected when a puppet show is held by a puppeteer. Therefore, it is a challenge for a puppeteer to be able to bring the Gathutkaca character to life in the show he holds. The puppeteer is also required to be able to amaze the audience who is waiting for Gathutkaca's presence. However, it is not an easy thing for a puppeteer to bring the Gathutkacha character to life as the audience wishes.

The reason is that a puppeteer must have sufficient provisions and skills to be able to display and bring the Gathutkaca character to life properly. A dalang is framed in a series of conventions of pakeliran in holding wayang performances. These rules must be thoroughly understood and mastered, because a wayang performance called pakeliran has a unified garap element. The elements of garap on pakeliran that must be understood and mastered by the dalang include elements of garap catur, sabet, and iringan (Suyanto, 2020: 23-24). The three elements of garap pakeliran are a whole unity.

The existence of elements of garap catur and sabet must be mastered by a dalang, in order to bring the Gathutkaca character to life as the audience demands. In this case, there are difficulties in terms of the ability of the dalang to transform the depiction of Gathutkacha as an idea into an ideal element of garap catur and sabet. It is not enough to transform ideas into two elements of garap. A dalang is also required to carry out the execution of the stage. The execution of the stage referred to here is to mix elements of garap catur and sabet into a wayang performance with elements of garap iringan. It is this difficulty that has stimulated the artist to create a work of art entitled Abur-Aburan Gathutkaca: the Work of Sabet Motion of the Samberan War in the Classical Shadow Puppet Performing Arts.

Based on the above background, the artwork abur-aburan Gathutkaca sabet of Samberan war was created with several formulations of the problem being solved. The formulations of the problems that arise were: (1) How is the composition of Gathutkaca's sabet in the Samberan war style?, (2) How to compose narratives and dialogues that accurately describe Gathutkaca in a staging text?, (3) How to animate abur-aburan Gathutkaca's text in a staging text. The three formulations of the problem need to be solved, and then mixed into a work of wayang performance entitled Abur-aburan Gathutkaca: the Work of Sabet Motion of the Samberan War in the Classical Shadow Puppet Performing Arts which is described in this article.

The main goal in creating the work of Abur-aburan Gathutkaca: the Work of Sabet Motion of Samberan War in the Classical Shadow Puppet Performing Arts is to create and present a scene of garap sabet abur-aburan Gathutkaca of pakeliran Surakarta style in the Samberan war that can amaze the audience. In particular, the purpose of this creation is to: (1) design a scene of abur-aburan Gathutkacha in the Pakeliran Surakarta-style in the Samberan war,(2) present Abur-aburan Gathutkacha online on the youtube channel, (3) to document the creation and presentation of Abur-aburan Gathutkaca's in the Samberan war. The specific objectives in the third and fourth points mentioned at the same time become the important point of this work. The presentation of AburAburan Gathutkaca: the Work of Sabet Motion of the Samberan War in the Classical Shadow Puppet Performing Arts on the youtube channel provides the flexibility of access to documentation for connoisseurs of wayang kulit performances, as well as for researchers and students who need references regarding shadow puppet performances with the theme of the Gathutkaca character.

\section{Work Review}

The work review stage was carried out by the author in the process of the work creation. The existence of this work review is to show the originality of the work in the creation of research-based works of art. Therefore, it is necessary to mention the existence of a work review in this section, in order to minimize plagiarism of previous works. The works that have been reviewed in the process of this work are as follows.

The first work reviewed in the creation of this work is Kakawin Bharatayuddha by Empu Sedah and Panuluh. As already mentioned in the background, the Kakawin text mentions that the Gathutkaha character fought against Karna in the Baratayuda war on the $14^{\text {th }}$ day. The greatness of the Gathutkaca character in fighting the Kauravas 
army is depicted in such a powerful way. In contrast to the text of Kakawin Bharatayuddha which tells the story of Gathutkaca's supernatural powers in the Baratayuda war, this work chose the Parta Krama story that embodies the depiction of the greatness of the Gathutkaca character in war.

Parta Krama story tells about Arjuna's marriage to Sembadra. Gathutkaca received the task of finding the conditions for Arjuna's marriage in the form of Kebo Danu Pancal Panggung totaling one hundred and forty-four. Kebo Danu Pancal Panggung is a magical buffalo that is only owned by Bathara Guru in Kayangan Suralaya (Sudibyoprono, 1991:145) Gathutkaca must get the buffalo by defeating the buffalo herder who is a spirit. The incident of Gathutkaca defeating the buffalo herder became the focal point in the creation of the work entitled Abur-Aburan Gathutkaca: The Sabet Motion of Samberan War in the Classiccal Shadow Puppet Performing Arts.

The second work is a work of sabet abur-aburan presented by Catur Nugroho, a lecturer of S-1 Puppetry Arts Study Program, ISI Surakarta. Catur Nugroho's sabet abur-aburan work presents Samberan war in the realm of basic pakeliran techniques. The work was produced in 2020 and then became a reference for student learning materials in learning to perform. There are two differences in the work of sabet abur-aburan presented by Catur Nugroho. First, the work of Catur Nugroho, which is used as a reference for teaching materials, presents elements of garap sabet on various basic-level movements. The work that was created was intended to enrich the presentation of sabet abur-aburan by Catur Nugroho. Therefore, the element of garap sabet in this work is innovative exploratory which has a more complex level of motion variety.

The second difference is the selection of Gathutkaca's enemies in the Samberan war. Catur Nugroho's sabet Samberan work features a giant character with fire hair. The fire-haired giant, known as buta rambut geni in the puppetry, is a giant warrior figure from a kingdom of a certain clan in the wayang. However, in the work of Abur-aburan Gathutkaca: the Sabet Motion of Samberan War in the Classical Shadow Puppet Performing Arts, the herder character of Kebo Danu Pancal Panggung was chosen as the enemy of Gathutkaca. The buffalo herder named Dhadhungawuk is a spirit creature in the mythical level. The choice of Dhadhungawuk was based on the thought of the puppeteer, that fighting against invisible spirits is not an easy thing to do. Therefore, the variety of war movements in the elements of garap sabet of Samberan war of the Gathutkaca character has differences when facing a giant invisible enemy.

\section{Concept, Foundation, and Method of Work}

Abur-aburan Gathutkaca is a term for puppet movements in the elements of garap sabet pakeliran of classical shadow puppets. The term Gathutkaca abur-aburan derives from two words, namely abur in Javanese, and Gathutkaca which indicates the name of the puppet character. Poerwadarminta (1939:1) defined the word abur with a definition that shows the behavior of winged animals when traveling through the sky. The definition given by Poerwadarminta directs the understanding of the word flying in Indonesian, which is a movement of hovering in the air. The word abur which means to fly then becomes a reduplication word with the addition of the suffix an in Javanese, so that it becomes abur-aburan. The term abur-aburan Gathutkaca can be interpreted as a series of flight movements of the Gathutkaca figure like a winged animal (bird) that can float in the air.

Samberan is also a word that comes from the word samber in Javanese. Poerwadarminta (1939:541) defined the word samber with the definition of nyaut saka ndhuwur tumlorot mudhun. This definition directs the understanding of the word sambar in Indonesian (snatch; is snatched) which means an event that takes something from top to bottom very quickly which is then carried away. The understanding can be through the analogy of an eagle snatching a rabbit as its prey. The word sambar can also be interpreted as an event hitting something from top to bottom as an event being struck by lightning; disamber blêdhèk (Java)

The word samber in Javanese gets the suffix -an so that it becomes the word samberan which means to refer to events from the verb snatch. Furthermore, the word samberan became a term in the wayang movement to name the characteristics of the fighting style of the Gathutkaca figure. The Gathutkaca character has the ability to fight with the samberan stance, which is to grab or hit his enemy as fast as lightning repeatedly through the ability to fly high in the air. Enemies who were struck by Gathutkaca's attacks were so overwhelmed that they could not fend off any of Gathutkaca's lightning-fast attacks. The speed of Gathutkaca's strike which is as fast as lightning is understood by the dalang artist with the embodiment of the Gathutkaca wanda thathit puppet (Sastronaryatmo, 1981)

Gathutkaca's skill in flying and grabbing enemies with his very powerful depiction became the concept in the creation of this work. Gathukaca's masterful idea flew like an eagle in the sky, and his lightning-fast strike was transformed into the element of garap sabet. Suyanto explained that the elements of unsur garap sabet are all 
forms of expression of wayang movements in pakeliran, including techniques for holding, embedding, pulling, various movements, and puppet techniques of black out. The element of garap sabet can also be understood as all forms of puppeteer expression through the medium of wayang motion based on characterizations and the dramatics of pakeliran (Suyanto, 2020:39). Therefore, ideas about the awesomeness of Gathutkaca's fighting style are transformed into elements of garap sabet by paying attention to the characterizations between Gathutkaca and his enemy and the atmosphere that accompanies it.

Strengthening the character of Gathutkaca is done by selecting the enemy to be dueled, so the Parta Krama story where Gathutkaca borrowed a buffalo in Kayangan was chosen as a condition for his uncle's marriage. The scene was chosen because Gathutkaca met the Dhadhungawuk character, namely the giant genie who became the herder of the Kayangan buffalo called Kebo Danu Pancal Panggung (Sudibyoprono, 1991:145). Genie is understood as the invisible creature by the Javanese, so their appearance as the enemy of Gathutkaca is not common. The attitude of his fighting style must be different from that of the enemy, which is more often manifested in the form of visible characters or characters at the epic level. Characteristics of enemy characterizations who are invisible creatures (spirits) become a medium in the creation of gerak sabet in the Samberan war of the innovative exploratory Gathutkaca character in harmony with the figure's character and dramatic atmosphere.

The creation of the work of Abur-Aburan Gathutkaca: the Work of Sabet Motion of the Samberan War in the Classical Shadow Puppet Performing Arts does not stop at the stage of transforming ideas into elements of garap sabet. The creation of the Gathutkaca Samberan war movement needs to be turned into a performance, so that it becomes a show that can be enjoyed by the audience. Therefore, Aris Wahyudi's dramaturgical paradigm of puppets was used, namely sambung rapet and greget sahut. Sambung rapet covers the dramatic structure of wayang which includes the determination of themes, characterizations, plots and settings in a stage material in the form of a dramatic script (Wahyudi, 2014: 34-35). The events of the powerful battle of Gathutkaca against Dhadhungawuk can be tightly intertwined through the sambung-rapet concept which contains the dramatic structure of the work created. In addition, the determination of the characterizations, the dalang narration and the appropriate wayang dialogue can be mixed proportionally.

The execution of the performance was carried out to turn the script of the show into a work of art performance based on the concept of greget sahut. Greget sahut is the way a puppeteer actualizes a dramatic script that contains pakeliran events to create vivid events through the appearance of story events, dialogues, atmosphere, narration, sulukan and action figures in a performance (Wahyudi, 2014: 35-36). Through this greget-sahut concept, it can be understood that staging is the execution of a whole series of garap lakon, garap sabet, garap catur (dialogue and narration), and garap iringan into pakeliran; live puppet show. At the time of the execution of the performance, the work of the artist uses the convention rules of the Surakarta style pakeliran.

The method of creating works that was carried out starts from determining ideas, conducting studies of previous works, and literature studies. Through these stages, the concept of the work was formulated which was then realized with the theory of dramaturgy of wayang which includes sambung-rapet and greget-sahut. The process of embodiment of the work was carried out by searching for exploratory and innovative Gathutkaca gerak sabet and making dramatic scripts. After that, a staging simulation was carried out in the form of staging practice activities. The performance of the work was carried out after the training stage was considered to be good. The method of this work is described in detail as shown in chart one. 


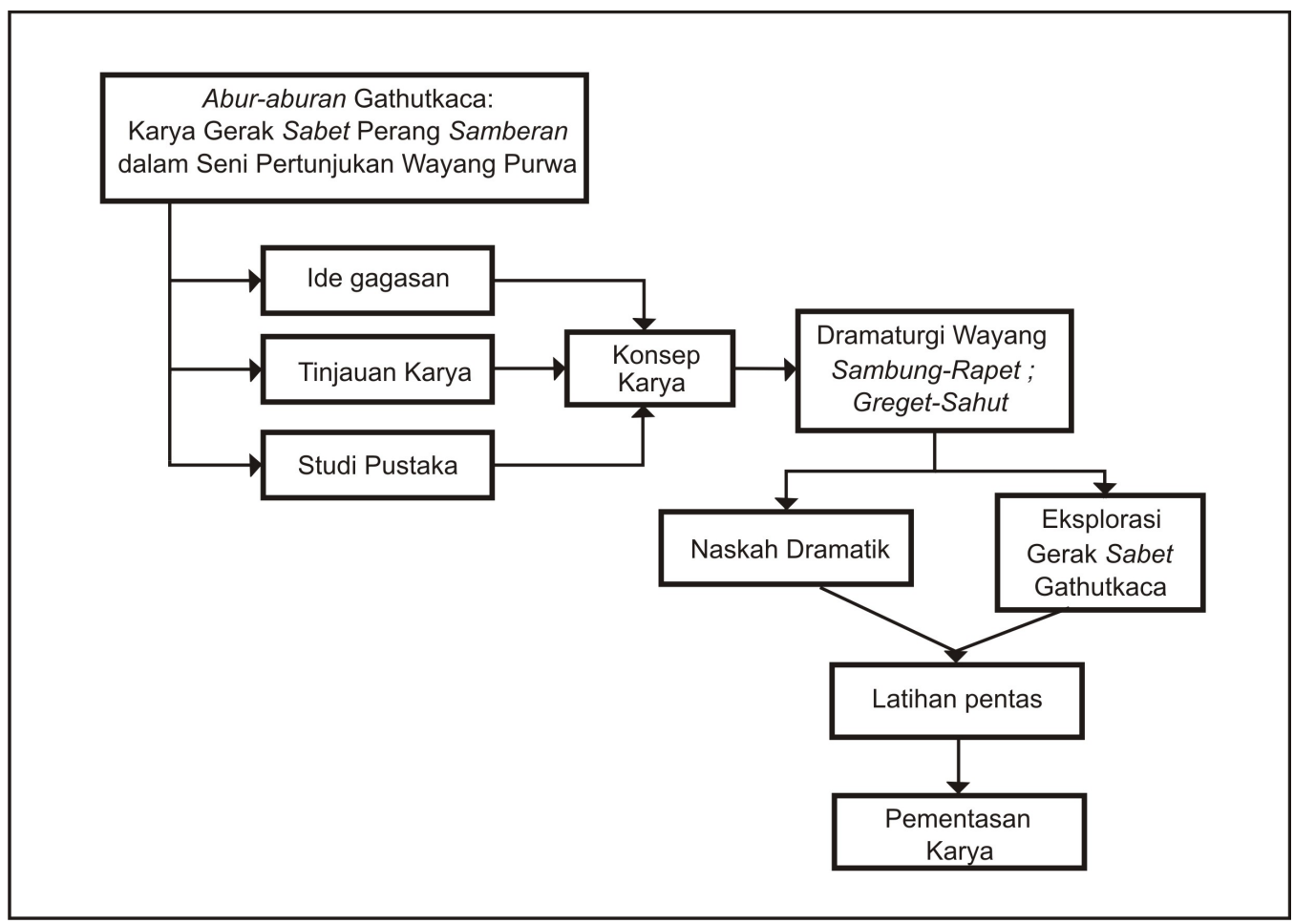

Diagram 1 Work Methods

\section{The Creative Process of the Work of Sabet Abur-aburan and Gathutkaca's Samberan War}

\subsection{Gerak Sabet Composition}

Sabet is one of the elements in garap pakeliran which deals with all forms of expression of the puppeteer through the medium of wayang motion in wayang or pakeliran performances. Sabet is also related to all forms of wayang performances in pakeliran. Therefore, the existence of sabet as one of the elements of garap pakeliran related to the technique of holding and enlivening puppets. In the Surakarta style pakeliran tradition, sabet has five elements which include cepengan, tancepan, solah, bedholan and entas-entasan (Suyanto, 2020:40). However, in order to make the composition of Gathutkaca's sabet in the style of Samberan war, the existence of the solah element in sabet is a special discussion in this article.

Suyanto explained the term solah as a term derived from the Javanese verb polah (2020:44). The word polah in Javanese has the meaning of doing activities, as Poerwadarminta (1939: 506) defined the word polah with the explanation of obahing angganing badan: body movement. Referring to this explanation, solah in the context of wayang is understood as everything related to the realization of the puppet movements performed by the dalang by giving the impression of life in pakeliran based on the atmosphere and character of the figures. As an embodiment of the motion of life from wayang, solah has several forms, one of which is the motion of war.

The composition of the war movements made in this work was carried out by taking into account the typical character of Gathutkaca. In wayang iconography, the figure of Gathutkaca has a body of gagah pideksa (extremely strong) with the characteristic shape of thelengan (=round full of eyeballs) eyes, pangotan nose (=the shape is similar to a knife used to leverage wood), has a rengon above the nose in front of his eyes, and has a mustache and sideburns (Suwarno, 2005: 8-34). The crown is decorated with Minangkara kinancing garudha mungkur bun hair, crowned in three layers, kalur ulur-ulur, has praba kencana on its back, and sor-soran jangkah kuncan katongan (Suwarno, 2005: 34-44). The iconography of the Gathutkaca character builds his dashing, haunted, and firm character. In addition, his capacity as a knight, as well as a young king in the Pringgadani country, illustrates his brave, responsible, and agile character in carrying out his duties (Suwandono, 1991:221). Therefore, in line with Nayawirangka (1958:55), Gathutkaca's war movement has an aesthetic movement that is steady, tough, confident, never avoiding things, and deadly when attacking.

Gathutkaca's range of flight movements in pakeliran include madal, mumbul, ndedel, nusup, miwir, mancat, and 
niyup. Madal is the first form of attitude when Gathutkaca is going to fly. The form of movement begins with the position of the left foot stepping forward, while the right foot behind for madal pratiwi or stepping on the earth. Mumbul is the second stage of attitude after mancat with the motion of lifting his body to take off. The next attitude is ndedel which is the attitude of flying by trying to rise straight into the sky as high as possible. The next attitude is nusup, which is a sneaking motion between the clouds that is carried out during a trip in the sky.

An attitude that is no less important is miwir. Miwir is the skill of processing the balance of the body while flying. Like an eagle, Gathutkaca could spread his wings to set the desired speed and height. Mancat attitude is understood as the attitude in Samberan war when the battle reaches its highest dramatic point. The mancat attitude was carried out after Gathutkaca managed to hold his enemy's head. Both Gathutkaca's feet pressed against his enemy's shoulders, while severing the enemy's head with a twisted technique with all his might; twisted (Java). The niyup attitude is the movement of flying in a reverse direction, and then sliding down at high speed with the head down. At the endpoint of the niyup attitude, the samberan stance: hitting the enemy with punches and kicks as fast as lightning was launched by Gathutkaca right at his enemy. When the enemy was overwhelmed and careless, and then he took a steady attitude and then twisted his enemy's head.

Based on the description above, garap sabet abur-aburan and Gathutkaca Samberan war was formulated by combining the basic movements of sabet that Gathutkaca character has. In addition, the basic rules in solah were also considered in order to reach the aesthetic stage. The creativity of the artist on garap sabet was also implemented so that garap sabet abur-aburan and Samberan war that is created showed an interesting side and an innovative creative value. To make this happen, the Parta Krama scene where Gathutkaca borrowed Kebo Danu Pancal Panggung was chosen as the venue. In that event, the figure of Gathutkaca fought with a giant character named Dhadhungawuk. As an illustration of the composition of gerak sabet abur-aburan and Gathutkaca's Samberan war, it is shown in tables one and two. The two tables are excerpts from the overall composition of gerak sabet made by the author.

\begin{tabular}{|l|l|}
\hline \multicolumn{2}{|l|}{ The description of Gerak Sabet Abur-aburan } \\
\hline Kayon & Gathutkaca \\
\hline Kayon appears from the left side of the screen. & $\begin{array}{l}\text { Gathutkaca appears from the right side of the } \\
\text { screen. }\end{array}$ \\
\hline $\begin{array}{l}\text { Moving forward with mendhak position } \\
\text { (Mendhak is a low standing position with the } \\
\text { knees bent. This bend is done with the thigh } \\
\text { open) to the middle of the screen. }\end{array}$ & $\begin{array}{l}\text { Moving forward with mendhak position (Mendhak } \\
\text { is a low standing position with the knees bent. This } \\
\text { the screen. }\end{array}$ \\
\hline Passing by & Rising up slowly \\
\hline Rising up slowly & Moving to the left \\
\hline Moving forward to the right & Turning back to the right \\
\hline Crossing & Moving to the right jumping over kayon \\
\hline & \multicolumn{2}{|l|}{} \\
\hline Moving to the left & Turning back to the left facing kayon. \\
\hline Crossing & Catching kayon with legs \\
\hline- & Swinging the kayon twice \\
\hline- & Sneaking into the kayon to the right and to the left, \\
\hline - & kentas left screen. \\
\hline - & \\
\hline
\end{tabular}

Table 1 One of the descriptions of Gathutkaca's gerak sabet abur-aburan made by the author. 


\begin{tabular}{|c|c|}
\hline \multicolumn{2}{|c|}{ The Description of Samberan War Motion } \\
\hline Dhadhungawuk & Gathutkaca \\
\hline \multicolumn{2}{|l|}{ Facing one another } \\
\hline- & Dugangan \\
\hline Avoiding & - \\
\hline Crashing & Flying \\
\hline \multicolumn{2}{|c|}{ Looking at each other from above and from below } \\
\hline- & Snatching to the left \\
\hline Dodging then catching but missing & - \\
\hline- & Snatching to the right \\
\hline Dodging then catching but missing & - \\
\hline- & Snatching to the left \\
\hline Dodging then catching but missing & - \\
\hline- & Snatching to the right \\
\hline Pulling Gathutkaca's feet down & - \\
\hline- & $\begin{array}{l}\text { Managed to escape, kicked Dhahungawuk's } \\
\text { head }\end{array}$ \\
\hline- & Snatching while kicking to the left \\
\hline In pain, kentas left screen & Catching after \\
\hline Crashing to the right and to the left & Dodging to the right and to the left \\
\hline- & $\begin{array}{l}\text { Kicking Dhadhungawuk's head three times, } \\
\text { snactching to the left }\end{array}$ \\
\hline- & Snatching again to the right \\
\hline Rolling & - \\
\hline- & Snatching over and over, kicking \\
\hline
\end{tabular}

Table 2 One of the descriptions of garap sabet of Gathutkaca Samberan war made by the author.

\subsection{Performance Materials}

This work is not enough to stop at the stage of creating sabet motion. Sabet motion created must be performed into a classical shadow puppet performance, so that it can be more alive and enjoyed by the audience. However, staging a classical shadow puppet requires stage material and the performance is like a drama show (Wahyudi, 2012: 18-19). The performance material is a performance text that contains themes, characterizations, plots, and settings in a performance structure. The performance material contains the dramatic structure of the performance in the form of a dramatic script which also presents dialogue, narration, and staging instructions. The themes, characterizations, plots and settings along with dialogue and narration as stage material are described as follows.

The theme in this work is rikat kaya kilat, kesit kadya thathit. The theme of rikat kaya kilat kesit kadya thathit in bahasa Indonesia means fast as lightning, agile as lightning strikes. This theme conveys a message about the power of Gathutkaca's fighting ability with the Samberan war style as the concept of the work described in the previous section. This theme is realized through characterizations, plots, and settings designed by the artist.

The characters that appear in this work include the figures of Gathutkaca, Petruk, Bagong, and Dhadhungawuk. Gathutkacha appears as the central character in this work, because Gathutkaca is the main character in the story. The characterization of Gathutkaca as the central figure rests on the concept of the work that has been described. As Soediro Satoto explained that the main character is a character who has the main role as the center of the story (1985:25). Therefore, it is appropriate for Gathutkaca to be the central figure in this work. Gathutkaha is shown as brave, tough, powerful, and responsible. 
The next figures are Petruk and Bagong who are servants of Raden Janaka who are also servants in Ngamarta country. In this work, Petruk and Bagong appear as Panakawan figures who accompany Gathutkaca in carrying out the task of searching for the Kayangan buffalo. The existence of Petruk and Bagong figures was raised in order to strengthen the characterization of Gathutkaca. Therefore, the two characters are positioned as supporting roles that appear in the first scene of this work. The supporting role is a role that is indirectly involved in the conflict that occurs (Satoto, 1985:25). The capacity of Petruk and Bagong as supporting roles does not let go of their character as Panakawan. Panakawan is a friend who escorts and guides his employer in the fulfillment of dharma, spiritual awareness, and self-maturity so that his employer continues to walk on the right track (Wicaksono, 2016: 287-289).

Dhadhungawuk character was positioned as an antagonist. An antagonist is a character who has the capacity as an opponent of the main character to create conflict (Satoto, 1985:25). The choice of Dhadhungawuk character has been explained in the description of the concept of the work in the previous section. In this work, Dhadhungawuk is characterized as a giant who was fierce, brutal, and agile in dealing with his combat opponents. The character of Dhadhungawuk which is made violent, brutal, and agile is made in order to strengthen the greatness of the Gathutkaca character in war. Therefore, the character of Dhadhungawuk appears in the third, fourth, and fifth scenes. The fifth scene is the climax of the dramatic tension of the story with the battle scene of Dhadhungawuk facing Gathutkaca.

When the themes and characterizations have been designed, the plot and setting of the story need to be determined. The plot used in this work is a linear plot. Linear plot is a chain of events that are sequential and continuous chronologically (Satoto, 1985:20-21). Therefore, the series of events that are arranged in realizing this work are made into five sequential scenes from the beginning to the end. This work starts from the first scene which shows the events of Gathutkaca preparing to carry out a mission to find Kebo Danu Pancal Panggung. Petruk and Bagong were also present to accompany Gathutkaca on his mission journey. The setting of this event took place in Ngamarta country square. After the three agreed to go looking for Kebo Danu Pancal Panggung, Gathutkaca set off by air travel with his ability to fly into the sky.

The next scene is the second scene which shows Gathutkaca flying through the sky. The second scene ended with Gathutkaca's flying speed reaching its maximum speed. The setting in this scene is the expanse of the sky. After that, the scene changes to the third scene which shows Dhadhungawuk with the setting of Kayangan. Dhadhungawuk appeared alone while complaining about his fate as a Kayangan buffalo herder called Kebo Danu Pancal Panggung. The total number of Kebo Danu Pancal Panggung is one hundred and forty. Bathara Guru entrusted the safety of the heavenly buffalo to Dhadhungawuk, so Dhadhungawuk felt that his task was not easy. All of the sudden, Dhadhungawuk was surprised because the buffalo he was herding ran scatteredly. Dhadhungawuk immediately checked and looked for the cause.

The scene changed to the fourth scene. Gathutkaca emerged from behind the clouds, and then met Dhadhungawuk. The two greeted each other, then stated their respective intentions. Gathutkaca immediately expressed his intention to borrow Kebo Danu Pancal Panggung, but Dhadhungawuk did not lend it. Dhadhungawuk actually considered the arrival of Gathutkaca threatening the existence of the Kayangan buffalo which was under Dhadhungawuk's supervision. The battle between Gathutkaca and Dhadhungawuk took place in the fifth scene. The events ended with Gathutkaca successfully defeating Dhadhungawuk.

Puppet shows, as well as drama shows, which show characters and their conflicts can come to life if they bring up conversations between characters called dialogue. This is like the uniqueness of wayang performances, namely the verbal aspect which is dominated by dialogue and narration. The term dialogue in the Surakarta style pakeliran tradition is commonly referred to as ginem (Nayawirangka, 1958:11-12). Besides ginem, there is still a narration which is the story of the dalang about the course of events in the pakeliran.

In the tradition of puppetry in the Surakarta style, the narrative that contains the storyteller of the puppeteer about the course of events in the pakeliran is divided into two forms, namely janturan and pocapan. Janturan is the narration of the dalang performed in a sirep gamelan music, while pocapan is performed by the dalang without gamelan music accompaniment (Nayawirangka, 1958:11). In this work, janturan and pocapan are made to strengthen the character of Gathutkaca and show the character of each figure. In the concocting process, pay attention to the archaic puppetry literature, as explained by Padmosoekotjo (1978).

The narration that shows the greatness of Gathutkaca is made in the form of pocapan. Pocapan fragments made in order to strengthen the characterization of Gathutkaca are as follows: 


\section{POCAPAN :}

.... dasar muda tumaruna sekti mandraguna, tan tadas tapak paluning pande sisaning grenda tanapi tedasing kikir. Bebasan tinatah mendat jinara menter Apa ta darunanae mangkono. Karana nalika isih jejabang Raden Gathutkaca kajedi ing kawah Candradimuka. Saranduning angga binumbon pusaka myang rajaning tosan. Otot kawat balung wesi, sungsum gegala, netra kumala lidah jingga, untu slaka menur, binrengosan pamor, sirah klonthongan wesi, pundak denda, lengen linggis, sikut pethel, driji gunting, epek-epek cakra, dadha blebekan waja, pupu bindi, dhengkul paron, gares cagak thing, lan dlamakan pacul.

The dialogue fragments made in order to show the greatness of Gathutkaca are shown as the following dialogue fragments.

\section{GATHUTKACA :}

Petruk kencengana sabuk ku. Aku nedya nggegana. Sarosamu nganti bakoh.

PETRUK:

Lha titikanipun menawi sampun kenceng menapa, Den?

$\underline{\text { GATHUTKACA : }}$

Yen aku ngeses lan nggereng.

..........

GATHUTKACA :

Durung krasa

PETRUK :

Krek... krek.rethethetettt... thet.. thet! Sampun gus?

GATHUTKACA :

Obah wae durung!

The battle scene is a scene towards the climax that occurs because of the conflict through the conversation between Gathutkaca and Dhadhungawuk. The conflict arose because Dhadhungawuk stated that he would not hand over Kebo Danu Pancal Panggung to Gathutkaca, while Gathutkaca insisted on borrowing it. Therefore, the two of them experienced more emotional tension, then the dramatic tension was raised with a special dialogue that led to an agreement to fight as an answer to the conflict that occurred. This special dialogue is understood in terms of challenges in the wayang dialogue. The dialogue of the challenges made is as follows.

\section{$\underline{\text { GATHUTKACA : }}$}

Sepisan maneh, tembungku mung nyilih minangka sarana bakal daupe pamanku. Aku ora niat apuskrama.

DADUNGAWUK :

Ora entuk! Aja maneh kok nyilih, nyedak apa nyawang wae ora kena! Gede wilalate! Yen ana cicir luwih-luwih kebo ndanu kapilara aku kang nampa dhendhaning Hyang Bathara Guru. Hayo, baliya Gathutkaca!

$\underline{\text { GATHUTKACA : }}$

Gelem bali lamun wus antuk gawe.

DADUNGAWUK :

Wah, njarag prekara! Ora sumingkir, kelakon ana bocah bagus tak pulasara!

GATHUTKACA :

Hayo jajalen!

DADUNGAWUK : 
Wah, kokop getihmu!

\subsection{Work Performance}

The performance of the work was carried out according to the rules of the Surakarta Style pakeliran convention which includes garap iringan either keprakan, sulukan, and the accompaniment of gamelan or gendhing used. The convention rules of the Surakarta style pakeliran have their own differences and characteristics in their performance when compared to other wayang styles. Therefore, the rules of the Surakarta style pakeliran convention need to be strictly enforced in the performance of the work. The course of the performances is described briefly as follows.

Kayon puppet stuck in the middle of the screen. The accompaniment of Sampak Laras Slendro Pathet Sanga was sung by gamelan players, so the staging of the first scene began. The dalang pulled out the kayon that is in the middle of the screen, then pluged it into the right side of the screen. The figure of Gathutkaca from the right along with the movement of the kayon is as a depiction of a strong wind blowing. Ki Lurah Petruk also appeared to dance with the change of accompaniment from Sampak Laras Slendro Pathet Sanga to gendhing dolanan entitled Repat Panakawan. Petruk also danced towards the left side of the screen, then plugged it into the bottom gedebog of the left side of the screen. After that, Bagong appeared while singing towards the left side of the screen. Arriving at the left screen, Bagong was stuck behind Petruk.

Iringan suwuk or stop was played by gamelan players. The conversation between Gathutkaca with Petruk and Bagong took place. The content of the conversation is about Gathutkaca's task to find the Kayangan buffalo called Kebo Danu Pancal Panggung. There were one hundred and forty tails of Kayangan buffalo. Gathutkacha must succeed in getting it as a condition for the marriage of his uncle, Arjuna. The conversation that took place was interspersed with humor that was uttered by Petruk and Bagong as a spectacle in the show. Finally, Petruk and Bagong were willing to follow Gathutkaca in carrying out a mission to find Kebo Danu Pancal Panggung. Before leaving, Gathutkaca ordered Petruk to fasten his belt. The accompaniment of Sampak Laras Slendro Pathet Sanga was again played by gamelan players. Raden Gathutkaca capeng then flew through the sky. The accompaniment of Sampak Laras Slendro Pathet Sanga became seseg or fast its rhythm with a signal of keprakan by the dalang.

The event continued with the second scene. Gathutkaca flew through the sky accompanied by palaran. The dalang performed an exploratory game of kayon to illustrate Gathutkaca's skill in flying. Gathutkaca repeatedly crossed, infiltrated, and exposed the game of kayon depicting clumps of clouds in the sky. After finishing the palaran, Sampak Laras Slendro Pathet Sanga played by gamelan players became seseg in rhythm. Raden Gathutkaca is described as flying as fast as lightning to continue his journey to find Kebo Danu Pancal Panggung.

The second scene changed to the third scene marked by the appearance of Dhadhungawuk accompanied by iringan lancaran. Dhadhungawuk moved violently and furiously; depicting the character of a rugged giant. After Dhadhungawuk moved violently and furiously, he stepped in the left side of the screen. The dalang applied iringan Sampak Laras Slendro Pathet Sanga with aba-aba dhodhogan, then narrates janturan which depicts the form of Dhadhungawuk. After the janturan narration was completed, iringan suwuk was followed by the song macapat pucung sung by Dhadhungawuk. Dhadhungawuk appeared to be in dialogue alone. He complained about his fate as a Kayangan buffalo herder who had to be responsible for the safety of one hundred and forty Kebo Danu Pancal Panggung. Suddenly, Dhadhungawuk saw the buffalo running helter-skelter, so he immediately approached Kebo Danu Pancal Panggung to find out the cause. Dhadhungawuk moved in a very acrobatic manner like a violent giant character.

The scene changed to the fourth scene. Raden Gathutkaca flew through the clouds, and then he met Dhadhungawuk. The accompaniment of Sampak Laras Slendro Pathet Sanga suwuk was followed by Suluk Adaada Greget sahut Sanga Wetah with a snippet of Kakawin Bharatayuda. After that, the dialogue between Gathutkaca and Dhadhungawuk took place. Dhadhungawuk praised Gathutkaca's good looks and bravery as a formidable warrior. Dhadhungawuk also asked for the name and purpose of Gathutkaca's arrival, causing the Kebo Danu Pancal Panggung to be disturbed. Gathutkaca also said his identity along with its aims and objectives. In this scene, humor was interspersed between Dhadhungawuk and Punakawan as a form of spectacle in the performance.

Dhadhungawuk said that he did not accept Gathutkaca's actions which had disturbed Kebo Danu Pancal Panggung. However, Gathutkaca did not feel bothered by the buffaloes. Gathutkaca really didn't see the existence of Kebo Danu Pancal Panggung, so it was impossible for him to disturb him. Dhadhungawuk stated 
that Kebo Danu Pancal Panggung, numbering one hundred and forty, was a magical and special buffalo. Gathutkaca also felt lucky to hear Dhadhungawuk's explanation. Gathutkaca immediately asked Dadhungawuk for help to lend him the Kebo Danu Pancal Panggung. Dhadhungawuk was surprised to hear Gathutkaca's request accompanied by Sampak Laras Slendro Pathet Sanga. Dhadhungwuk again moved furious and violent. The accompaniment of Sampak Laras Slendro Pathet Sanga suwuk was continued by Ada-ada Pathet Sanga Jugag. Dhadhungawuk did not agree to Gathutkaca's request. Finally, the battle between the two occurred.

The Sampak Laras Slendro Pathet Sanga accompaniment rang again to accompany the battle between Gathutkaca and Dhadhungawuk. Dhadhungawuk was about to bite Gathutkaca in a huff, but Gathutkaca was able to dodge quickly. Dhadhungawuk then bit Panakawan Petruk as a form of gecul war. Gecul war was presented exploratively in order to bring out the humor of motion that happened spontaneously. The war between Gathutkaca and Dhadhungawuk was exciting and powerful. Dhadhungawuk was very fierce and violent with movements of somersault, bridge position, rolling, biting, and pouncing. Gathutkacha continued to fight with tact because Dhadhungawuk was an untouchable spirit. After Gathutkacha was able to concentrate his mind, he issued his signature move, namely Samberan war.

Gathutkacha's stance was launched to Dhadhungawuk. His movements are energetic, very agile, and always on target. His speed was lightning fast, so Dhadhungawuk didn't get a chance to retaliate. Dhadhungawuk was beaten by Gathutkacha until he fell up and down. Dhadhungawuk was overwhelmed by Gathutkaca because his bite did not injure Gathutkaca at all. His attacks did not hit at all, instead, Gathutkaca attacked him over and over. The Samberan war motion was displayed as the composition has been made. Dhadhungawuk's defeat was marked by the success of Gathutkaca rising on Dhadhungawuk's shoulders and holding the giant head of the buffalo herder. The war scene ends with kayon's exploratory motion. The performance was really completed with the kayon mark stuck in the middle of the top gedebog screen. The accompaniment of Sampak Laras Slendro Pathet Sanga has stopped playing.

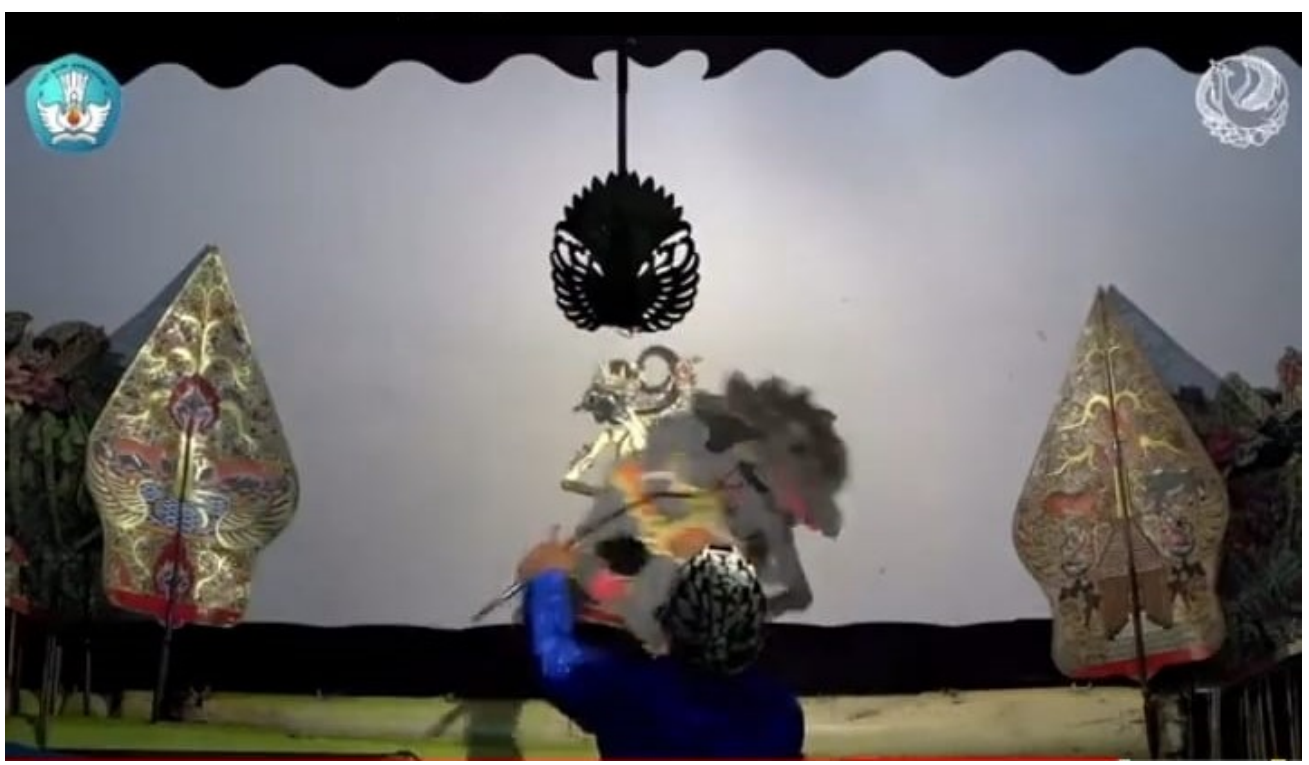

Figure 1 Work Performance Documentation

\section{Conclusion}

In this work, garap sabet abur-aburan and Samberan war must be creative and innovative. The search for the exploratory form of Gathutkaca's sabet was carried out by means of repeated exploration. However, the basic principles of cepengan, tanceban, bedholan, and solah elements in garap sabet of classical shadow puppet cannot be abandoned. The consideration is none other than the issue of achieving the aesthetic value of wayang performances in displaying sabet abur-aburan and Samberan war in pakeliran. Creativity and innovation carried out in garap sabet also need to be carried out with in-depth exploration of the wanda wadana rules of the Gathutkacha figure. The characters and their capacities also need to be considered.

Basically, this work is not final. There are still many things that can still be perfected by carrying out further 
work related to garap sabet and Saberan war of the Gathutkaca character. All criticism and suggestions for the perfection of this work are very welcome. The author hopes that another author can further develop what has been done by the current artist. Hopefully, knowledge in the field of puppetry and their works of art can be more developed and useful for the community.

\section{References}

Nayawirangka. (1958), “Serat Tuntunan Pedalangan Lampahan Irawan Rabi”, Jogjakarta, Tjabang Bagian Bahasa Djawatan Kebudajaan, Kementrian P.P dan K.

Padmosoekotjo. (1978), “Suluk Pedalangan”, Surabaya, PT Citra Jaya Murti.

Poerwadarminta, W.J.S. (1939), "Baoesastra Djawa”, Batavia, L.B Wolters Uitgevers Maatschappij N.V.

Sastronaryatmo. (1981), "Wanda Ringgit Purwa”, Jakarta, Departemen Pendidikan dan Kebudayaan.

Satoto, Soediro. (1985), "Wayang Kulit Purwa Makna dan Struktur Dramatiknya", Yogyakarta, Proyek Penelitian dan Pengkajian Kebudayaan Nusantara (Javanologi) Direktorat Jendral Kebudayaan Departemen Pendidikan dan Kebudayaan.

Sudibyoprono, R. Rio. (1991), “Ensiklopedi Wayang Purwa”, Jakarta, Balai Pustaka.

Suwandono. (1991), “Ensiklopedi Wayang Purwa”, Jakarta, Balai Pustaka.

Suwarno, Bambang. (2005), “Teknik Pembuatan Wayang”, Yogyakarta, Senawangi.

Suyanto. (2020), “Pengetahuan Dasar Teori dan Petunjuk Teknik Belajar Mendalang”, Surakarta, ISI Press.

Wahyudi, Aris. (2012), "Lakon Dewa Ruci Cara Menjadi Jawa Sebuah Analisis Strukturalisme Levi-Strauss dalam Kajian Wayang”, Yogyakarta, Bagaskara.

Wahyudi, Aris. (2014), "Sambung-Rapet dan Greget-Sahut: Sebuah Paradigma Dramaturgi Wayang", Yogyakarta, Bagaskara.

Wicaksono, Andi. (2016), "Makna Lakon Alap-alapan Sukesi Sebuah Analisis Hermeneutik", Thesis S-2 Program Pascasarjan, ISI Yogyakarta. 